International Research Journal of Management, IT \& Social Sciences
Available online at https://sloap.org/journals/index.php/irjmis/
Vol. 6 No. 1, January 2019, pages: 63 69
ISSN: 2395-7492
https://doi.org/10.21744/irjmis.v6n1.583

\title{
Tourism as Leading Sector for Foreign Exchange Contributors with Government Policy Efforts through Visa-Free Visits in Bali
}

\begin{tabular}{|c|c|}
\hline & $\begin{array}{l}\text { A.A. Gde Putra Pemayun } \\
\text { I Gusti Ngurah Putra Suryanata }\end{array}$ \\
\hline Article history: & Abstract \\
\hline $\begin{array}{l}\text { Received: } 18 \text { July } 2018 \\
\text { Accepted: } 30 \text { November } 2018 \\
\text { Published: } 16 \text { January } 2019\end{array}$ & $\begin{array}{l}\text { The purpose of this study is to find out the visit visa-free policy can reach the } \\
\text { target of tourist visits in Bali. Public policy is a series of interconnected choices } \\
\text { (including decisions not to act) made by government bodies or officials, } \\
\text { formulated in the fields of land, energy, and health to education, welfare, and } \\
\text { crime. Policy implementation is the implementation of policies that have been } \\
\text { formulated and lead to the results obtained in the form of the policy itself and } \\
\text { the benefits that can be felt by the community so that the implementation of }\end{array}$ \\
\hline $\begin{array}{l}\text { Keywords: } \\
\text { foreign exchange contributors; } \\
\text { government policy efforts; } \\
\text { leading sector; } \\
\text { tourism; } \\
\text { visa-free visits; }\end{array}$ & $\begin{array}{l}\text { the policy needs to be studied more deeply. Implementation is an important } \\
\text { aspect of the overall policy process that produces output. Visit visa-free policy } \\
\text { is not the only major determinant that attracts foreign tourists to Bali, foreign } \\
\text { tourists come to visit because the area is indeed interesting to visit, in line with } \\
\text { this, the government is now beginning to exploit existing tourism potentials, } \\
\text { encouraging participation active community and supporting with other } \\
\text { facilities, however, the visit visa-free policy is an efficient and easy to } \\
\text { implement program to achieve greater foreign tourist visits. The results of the } \\
\text { study show that the visit visa-free policy can increase foreign tourist visits to } \\
\text { Bali exceeding the target because tourists feel the ease of traveling anywhere } \\
\text { in Indonesia, especially in Bali which has been famous for tourist objects } \\
\text { abroad international disguised as tourists so as not to use Bali as their final } \\
\text { destination. }\end{array}$ \\
\hline
\end{tabular}

2395-7492 (C) Copyright 2019. The Author. This is an open-access article under the CC BY-SA license (https://creativecommons.org/licenses/by-sa/4.0/) All rights reserved.

\section{Author correspondence:}

A. A. Gde Putra Pemayun,

Department of Management, Faculty of Economics and Business, Universitas Pendidikan Nasional

Jalan Bedugul No.39 Sidakarya Denpasar, Bali, Post Code: 80255, Indonesia, Ph. +6281236522303

Email address: putra.pemayun@gmail.com

\footnotetext{
a Department of Management, Faculty of Economics and Business, Universitas Pendidikan Nasional, Denpasar, Indonesia

${ }^{\mathrm{b}}$ Department of Management, Faculty of Economics and Business, Universitas Pendidikan Nasional, Denpasar, Indonesia
} 


\section{Introduction}

Globalization is an era of competition and openness in the world, it can be felt more free human and goods movements such as goods and services, technology, science, and social culture. The government must strengthen competitiveness in the field of goods and services, technology and human resources because good management of human resources is directly proportional to the progress of the nation so as not to lag behind other countries. The life of the world community is now entering the phase or era of new economic models, namely unlimited and non-stop growth and free trade between nations which are agreed upon crisis after crisis. In realizing the hope of the prosperous community the government strives and maximizes the various potentials of the nation to make commodities that benefit all nations. One of them is by making the tourism sector a leading sector. Brata \& Pemayun (2018), the tourism sector is an industry component that produces the fastest compared to other industries. The richness of Balinese culture and the beauty of nature, art and culture are great potentials in the development of the tourism sector to increase foreign exchange and create extensive employment opportunities for Balinese people through various related supporting industries such as Hotels, Restaurants, Tours and travel, creative industries, entertainment, and others. At present the change in world civilization changes the outlook of its society to make recreation and lifestyle as a more important requirement of shopping, thus becoming an opportunity for Bali to open new destinations and improve existing destinations so that Bali tourism becomes a superior and attract tourists (Pemayun \& Brata, 2018; Amerta, 2017; Pemayun \& Maheswari, 2017). At present, Chinese tourist arrivals are increasing to various parts of the world reaching 250 million people with an estimated visit to Bali of 6 million people. The government applies visa-free visits to 169 countries around the world to be able to enter the territory of Indonesia and Bali especially without the obligation to have a visa. With this policy, it can be one of the stimuli for developed economies in the world. It is estimated that the Indonesian government can meet the target of 25 million foreign tourist arrivals in 2020. The various efforts of the provincial government of Bali to maintain the security and comfort of tourists visiting tourism destinations both Ubud, Gianyar, Badung, and Klungkung with Nusa Penida Island have jasmine hotels and star and a panorama of nature and sea that attract foreign and domestic tourists.

\section{Literature Review}

Dhesinta (2017), research entitled immigration control function in control of radicalism post-implementation of visa-free visa policy. It was stipulated through Presidential Decree No. 69 in 2015 to increase the country foreign exchange in the tourism sector, in fact not free from a number of potential problems. It was devoted to the 169 countries open opportunities for issues not only to visa permits misuse for visiting but also of potential spread for radicalism and terrorism. The country is mostly Muslim. Indonesia is increasingly becoming the target of the radicalism spread. Therefore, the immigration role becomes the gate guardian of the state sovereignty is very necessary. In this case, the study is focused on how the function of immigration supervision in controlling radicalism in Indonesia after applied to visa-free visit policy. It is conducted regarding the selective policy principle. The immigration control is carried out not only when foreigners leave or enter Indonesian territory but also when foreigners are in Indonesian territory. The results are expected to be supervised by the Directorate General of Immigration towards foreigners conducted by administrative supervision actions of immigration and field supervision. In conclusion, the supervisory function possessed by immigration in controlling the potential radicalism and even terrorism can work well, if it is synergy between immigration, Indonesian National Police, National Agency for Combating Terrorism (BNPT), and the active participation of the society in overseeing the foreigners activities in Indonesia.

Nugroho (2017), research entitled optimizing the role of Timpora post regulation of president no. 21 in 2016 on a visa-free visa. It was applied the mixed approach (quantitative and qualitative). The primary data is obtained in the field of respondents. The secondary data is collected based on a literature search, research data, regulations, theories, and other documentation. The research is focused on a regulation related to foreign supervision, a supervisory mechanism for foreigner and constraints faced by Timpora after the Government Regulation No. 21 in 2016 on a visafree visa. The results were obtained (1) the foreigner's supervision is more completeness matter of documents or immigration administration. The authority is dominated by immigration officials, related to agencies are limited to providing feedback or suggestions regarding foreigners information. (2) the administrative oversight mechanism is more detailed than the control over the presence and foreigners activities. (3) the constraints are limited to the personnel number, the lack of competence owned by Timpora members, thus, it becomes a problem when conducted monitoring, checking, intelligence activities. The coordination has not done well. It is still a sectoral ego for supervision execution. The minimum budget also becomes an obstacle to issuing implementation. It is necessary to evaluate Presidential 
Regulation No. 21 in 2016 on visa-free visits and to tighten the countries cause issues, increase synergy, coordination, and eliminate sectoral ego for each institution formally and informally. Respecting the two above studies, this study is different due to it examines the economic benefits of government revenues and wide open employment opportunities for the society in increasing foreign tourists visiting Bali.

\section{Materials and Methods}

Types and data sources

The data that is used in the present research:

1) Primary data, i.e. data, and information obtained directly from sources/respondents. This data was obtained by conducting interviews with immigration staff and tourists visiting Bali. By using proportional sampling technique with six samples of immigration staff and ten foreign tourists.

2) Secondary data, i.e., data and supporting information obtained from the Denpasar Immigration Office and other relevant data.

\section{Specification of the research model}

Macroeconomic Theory (Budiono, 2010). Basically, the macroeconomic theory is a theory that studies and discusses all events, phenomena or problems related to the economy as a whole or in a large scope. Macroeconomics is also a part of economics that focuses on the study of the mechanism of economic work of a nation as a whole. The purpose of macroeconomics is to understand and understand events or events around the economy and strive to create a formula that becomes a solution to improve existing economic policies.

Public Policy Theory of Van Metter and Van Horn in Agustino (2008). Every policy issued by the government has several variables affecting the performance of its implementation as follows (1) The size and policy objectives of performance policy implementation can be measured success if the size and purpose of the policy is realistic with the socio (2) Resources that are human, financial and time resources (3) Characteristics of implementing agencies include formal organizations and informal organizations that will be involved in the implementation of public policy including the area of policy implementation. (4) Disposition of executors includes knowledge and understanding of content and policy objectives as well as acceptance and rejection of the implementers (5) Interorganizational communication and implementing activities i.e., coordination between the parties involved in an implementation process. (6) The economic, public, and political environment is the extent to which the external environment contributes to the success of the established public policy.

\section{Research Location}

The location of this study is in Denpasar Bali immigration office by observing and mapping community activities in a measurable manner. The time of observation as an object of analysis is the condition of 12 (twelve) months from January to December in 2018. Consideration of the use of 2018 is taken to facilitate the recording of information on respondents, namely, tourists and Denpasar Bali immigration officers.

\section{Research Instrument}

The instruments used in this study were descriptive research through literature surveys and field surveys and in-depth interviews. The interviews conducted were open questions and closed questions ended.

\section{Method of Data Analysis}

Macroeconomic theory (Budiono, 2010). The government has five issues of economic policies throughout 2016, i.e., policy packages IX through XIV. The policy package covers policies in the industrial, investment, community empowerment, logistics, exports, and national tourism sectors. The policy indeed is expected to reduce the various barriers of activity economic, consumption, investment, production, and international trade. Thus, the domestic economy can grow better. Economic Center of Reform on Economics (CORE) Indonesia is explored not all packages can be assessed impact fastly. The policy golding part is related to improving the business climate has a time-lag for

Pemayun, A. G. P., \& Suryanata, I. G. N. P. (2019). Tourism as leading sector for foreign exchange contributors with government policy efforts through visa-free visits in Bali. International Research Journal of Management, IT and Social Sciences, 6(1), 63-69. https://doi.org/10.21744/irjmis.v6n1.583 
the entrepreneurs. The weak domestic and global demand makes the policy impact on domestic economic activities not significant. Some policy packages are not expected to have an effective impact, either from a technical point of view implementation or in terms of the policy substance. The dissemination related to the parties is still low while policy implementation by ministries or agencies is also slow and some policy packages are difficult to evaluate progress. Due to they do not have measurable time targets. Regarding the policy substance side, some policies are still partial and have not touched upon the issue substance will be resolved. The policy package $\mathrm{X}$ revising of the Presidential Regulation (Perpres) No. 39 in 2014 on the negative list of investment with the objective of protecting small entrepreneurs and giving certainty on the foreign ownership limits. The policy contents encourage more liberalization of foreign investment in various sectors which would potentially reduce the domestic role of entrepreneurs in economic development national (Akbar, 2016). It is highlighted by XI policy package related to the export-oriented people business credit provides a complete and integrated export financing facility for working capital and investment for export destinations for MSMEs. The interest rate is $9 \%$ without subsidies. There are some packages shortcomings, the partial policy approach, non-integrative, and no insurer specific responsibilities that monitor and coordinate all related policies. The policy only touches the financing aspect. The credit program is limited to only IDR. 1 trillion in 2016 and the interest rate is 9\%, not unlike credit program people business (KUR) set in the APBN with interest rate of $9 \%$. The low socialization makes this facility cannot be exploited widely by object policy.

Public policy theory (Van Metter and Van Horn in Agustino, 2008). The target of foreign tourist arrivals is 25 million in 2020 for Indonesia and Bali is 8 million foreign tourists according to the government is a realistic target to achieve given the potential for Indonesian tourism attraction is very much both in terms of nature tourism, cultural tourism, and artificial tourism, regarding other countries unlike Singapore and Malaysia that get foreign tourist visit far beyond Indonesia. The qualified and professional human resources as required by the policy. If the resources competence is low then the public policy performance is as well as low. The human resources outside are other resources that need to be taken into account included financial resources and time resources. Related to human resources directly involved in the free visa process. The visitation in Bali is immigration officer at immigration checkpoints in Bali included I Gusti Ngurah Rai International Airport, Benoa Seaport, Padang Bai Seaport, and Celukan Bawang Seaport. Free visa policy does not need to be implemented in the extreme by lowering the implementation agent who has a hard character and strict rules. As it is, Visa-free visits policy is a persuasive and soft policy toward visa rules in cross-country crossings. This is due to the main purpose of Visa-free visits policy is to bring as many foreign tourists as possible visiting Bali.

The immigration officers as the attitudes representation or tendencies for its agencies as well as the Department of Tourism is very interested in the implementation performance of visa-free visits policy. It already has a sufficient understanding of the meaning and policy purpose and how to implement it. It does not escape from the leader's role in conducting their guidance, advice, and clarity of technical guidance. Some synergy agencies in creating a conducive tourism environment, safe, comfortable, and attract foreign tourists is very important. The communication between policy implementers finds a solution to the issue occurs regarding visa-free policy visits in Bali. Bali developments are very fast compared to other areas in Indonesia. Due to the social culture change originally only rely on agricultural products shifted to the tourism sector as a regional income the main. The government is one of supporting actors to increase the foreign tourists visiting Bali, to increase the economic benefits and the people welfare.

\section{Results and Discussions}

The macroeconomic policy coordinated by Indonesia Central Bank signed economic improvement based on the achievement of the second quarter in 2016 growth that exceeded expectations. However, there are some global economic uncertainty factors central bank is hesitant in deciding to loosen monetary policy. The following Indonesia Governor Bank (Warjiyo, 2017), stated that must assess the risk and condition of the financial market to determine monetary policy direction in the future. Despite, the economic growth in the country shows signs of strengthening, there is still a global economy risk, therefore, the risk assessments and past market outlook. The bank is still looking for a good time to loosen its policy by taking into account two global economic factors. The monetary easing in June and July a precise time compared to November and December. First, financial market conditions face risks of rate United States (US) is the fed rate. Since, at the beginning of 2018, the US Central Bank has indicated. It will again hoist interest rates. But, the policy currently has not been implemented due to the economic conditions have not improved. Second, the belief that economic growth already fundamentally improved. Consideration, there is still a risk to the out impact for the UK from the European Union (Britain Exit/Brexit) to the world economy and Indonesia. The 
commodity prices are expected to remain unchanged of the policy changes by the Chinese government. Due to export remaining unchanged until the year-end, due to China is one of Indonesia main trading partners. The two risk factors are the reasons why Indonesia Central Bank has not intended to raise the economic growth projection of $5.1 \%$ in 2018. Although, the economic was growth realization in quarter II 2016 above expectations earlier is $5.18 \%$ and overall in the semester I 2016 grew 5.04\%. There is still some uncertainty in the third quarter and IV. Indonesia Central Bank is still reviewing the planned budget cuts amounting to IDR. 133.8 trillion to the economy. The central bank estimates that the policy impact is not too great throughout the government not cutting productive spending, as for infrastructure projects. Moreover, the government absorption so far spending is always under target. If the budget cuts followed by an increase in budget absorption, it will still be able to encourage economic growth. If the absorption (budget) reaches $90 \%$ to $95 \%$, the effect is not much (on economic growth). Basically, the economic development of the state aims to achieve society prosperity through the high economic growth and income equitable distribution by creating the widest work field.

Visa-free visits policy in Bali is conducted through several implementation process stages among training executor, public dissemination, and full implementation. Some stages unlike team building and implementation trials are not conducted due each implementer have a good role in their implementation of visa-free visits policy. If the trial is not implemented due visa-free visa policy is not a new policy, the only strategy is to make adjustments to the subject states list it to the implementation of Border Control Management (BCM) system of the Directorate General of Immigration set the immigration checkpoint and connected via the Immigration Information System to the Immigration Data Center at the Immigration General Directorate. If the current stage of the policy improvement has not been conducted due to the evaluation of visa-free visitor policy has not been thoroughly conducted on the policy performance linked to the policy formulation itself. Every policy applied needs to be evaluated to measure executing officers performance can be measured by achievement level and issues arising from the policy, therefore, the solution will be immediately found. The future will get maximum results.

\section{Conclusion}

Macroeconomic policies in Indonesia and Bali particularly by looking at the economic improvement signs based on the achievement of the second quarter in 2016 growth beyond expectations. Indonesia Central Bank must assess the risks and financial market conditions to determine the aims of the future monetary policy. Due to the economic growth in the country shows strengthening signs, there are still risks to the global economy for the risk assessment and the last financial market view. The bank is still looking for a good time to loosen its policy by paying attention to the two factors of the global economy. The monetary easing in June and July was a good time compared to November and December. First, the financial market conditions face rising risks of US interest rates United (US) is the fed rate. There are still risks to the out impact of UK from the European Union (Britain's Exit/Brexit) on the world economy and Bali. The economic development of the state aims to achieve social prosperity and the creation of wide-ranging employment opportunities. Visa-free policy visits in Bali are conducted by immigration officers at immigration checkpoints in I Gusti Ngurah Rai International Airport, Benoa Seaport, Padang Bai Seaport, and Celukan Bawang Seaport. The affairs related to the persons passage entering or leaving the Indonesia territory either through airports, seaports or crossborder posts are carried out by the immigration apparatus. The policy does not need to be applied in the extreme by lowering the actors who have strong character and strict rules. As it is, the policy is a persuasive and soft policy toward visa rules in cross-country. It is occurred due to the main purpose of visa-free visits policy is to bring many foreign tourists as possible to Bali. Bali, unlike a world-renowned tourist destination, is also the largest contributor to the foreign exchange.

\section{Conflict of interest statement and funding sources}

The authors declared that they have no competing interest. The study was financed by the authors.

\section{Statement of authorship}

The authors have a responsibility for the conception and design of the study. The authors have approved the final article.

\section{Acknowledgments}

The authors would like thanks the editor of IRJMIS for their support, advice, and valuable time.

Pemayun, A. G. P., \& Suryanata, I. G. N. P. (2019). Tourism as leading sector for foreign exchange contributors with government policy efforts through visa-free visits in Bali. International Research Journal of Management, IT and Social Sciences, 6(1), 63-69. https://doi.org/10.21744/irjmis.v6n1.583 


\section{References}

Akbar, S., Poletti-Hughes, J., El-Faitouri, R., \& Shah, S. Z. A. (2016). More on the relationship between corporate governance and firm performance in the UK: Evidence from the application of generalized method of moments estimation. Research in International Business and Finance, 38, 417-429. https://doi.org/10.1016/j.ribaf.2016.03.009

Amerta, I. M. S. (2017). Community based tourism development. International Journal of Social Sciences and Humanities, 1(3), 97-107. https://doi.org/10.29332/ijssh.v1n3.60

Brata, I. B., \& Pemayun, A. G. P. (2018). Interpersonal society of Satria Dalem. International Journal of Social Sciences and Humanities, 2(2), 115-123. https://doi.org/10.29332/ijssh.v2n2.150

Budiono, D. P., \& Martens, M. (2010). Mutual funds selection based on funds characteristics. Journal of Financial Research, 33(3), 249-265. https://doi.org/10.1111/j.1475-6803.2010.01270.x

Dhesinta, W. S. (2017, December). Kebijakan Bebas Visa Dan Fungsi Pengawasan Keimigrasian Dalam Pengendalian Radikalisme Di Indonesia. In Seminar Nasional Hukum Universitas Negeri Semarang (Vol. 3, No. 1, pp. 15-28). https://journal.unnes.ac.id/sju/index.php/snh/article/view/20916

Nugroho, T. W. A. (2017). Optimalisasi Peran Timpora Pasca Berlakunya Peraturan Presiden Nomor 21 Tahun 2016 Tentang Bebas Visa Kunjungan. Jurnal Ilmiah Kebijakan Hukum, 11(3), 263-285. http://dx.doi.org/10.30641/kebijakan.2017.V11.263-285

Pemayun, A. A. G. P., \& Brata, I. B. (2018). Implementation of tourism facilities expansion to hedonism and community imaging. International Journal of Social Sciences and Humanities, 2(1), 33-42. https://doi.org/10.29332/ijssh.v2n1.76

Pemayun, A. G. P., \& Maheswari, A. I. A. (2017). Economic impacts of craftsman statue on community based tourism development. International Journal of Social Sciences and Humanities, 1(3), 59-73. https://doi.org/10.29332/ijssh.v1n3.56

Van Horn, C. E., \& Van Meter, D. S. (1977). The implementation of intergovernmental policy. Policy studies review annual, 1(1), 97-120.

Van Meter, D. S., \& Van Horn, C. E. (1975). The policy implementation process: A conceptual framework. Administration \& Society, 6(4), 445-488. https://doi.org/10.1177\%2F009539977500600404

Warjiyo, P. (2017). Kebijakan Moneter di Indonesia (Vol. 6). Pusat Pendidikan Dan Studi Kebanksentralan (PPSK) Bank Indonesia. 


\section{Biography of Authors}

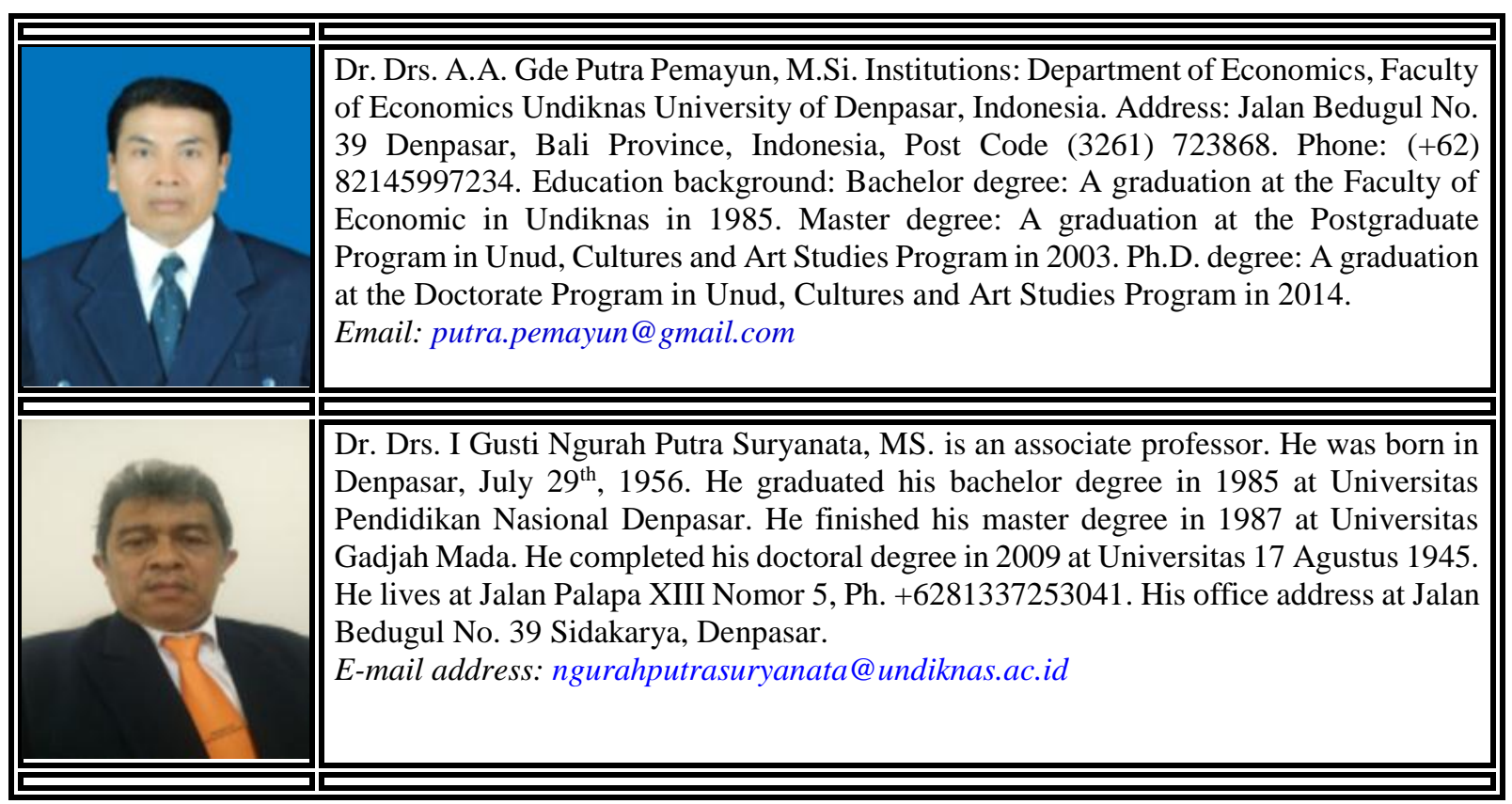

Pemayun, A. G. P., \& Suryanata, I. G. N. P. (2019). Tourism as leading sector for foreign exchange contributors with government policy efforts through visa-free visits in Bali. International Research Journal of Management, IT and Social Sciences, 6(1), 63-69. https://doi.org/10.21744/irjmis.v6n1.583 